\title{
Augmented Reality in Teaching Descriptive Geometry, Engineering and Computer Graphics - Systematic Review and Results of the Russian Teachers' Experience
}

\author{
Marianna V. Voronina ${ }^{1}$, Zlata O. Tretyakova ${ }^{1 *}$, Ekaterina G. Krivonozhkina ${ }^{2}$, Stanislav I. Buslaev ${ }^{3}$, \\ Grigory G. Sidorenko ${ }^{3}$ \\ ${ }^{1}$ Saint-Petersburg Mining University, Saint Petersburg, RUSSIA \\ ${ }^{2}$ Kazan (Volga region) Federal University, Kazan, RUSSIA \\ ${ }^{3}$ Financial University under the Government of the Russian Federation, Moscow, RUSSIA
}

Received 10 June 2019 - Revised 25 September 2019 • Accepted 14 October 2019

\begin{abstract}
The relevance and feasibility of this study are determined by the absence of serious, scientific research, as well as teaching materials, when it comes to the use of Augmented Reality (AR) in teaching students and future teachers Descriptive Geometry, Engineering and Computer Graphics (DGECG). The purpose of the study is to examine the current state of knowledge and practice of existing courses, which use the AR concept; to conduct a pedagogical experiment by teaching students how to create an information model of a building structure using the AR concept; to study the impact of the AR technology on students, lecturers, on the quality of students' design works and project presentation. The research methods used were a set of various, complementing each other methods, which can be divided into two groups: 1) theoretical: analysis of the teachers' and psychologists' works on the point of the research, analysis of methodological and educational literature; empirical: observation, statement, pedagogical experiment. The authors synthesized qualitative and quantitative AR research in the field of education. A team of students from SaintPetersburg Mining University, Kazan (Volga region) Federal University and Financial University under the Government of the Russian Federation solved a design problem using AR and created an informational 3D-model of the structure. Existing methods of teaching students were supplemented and updated by the method of graphical presentation of the results, with due regard for AR-technologies. It has been found that at the present moment, the concept of AR has gained popularity not only among designers and planners, but also among schoolteachers, as well as among teachers at engineering universities. The absence of scientifically substantiated and proven programs and training materials for training students of DGECG using AR has also been confirmed. The necessity of further scientific research in the field of AR for DGECG has been substantiated. The article materials could prove to be useful for lecturers, schoolteachers and parents.
\end{abstract}

Keywords: universities, students, teachers, educational technology, augmented reality $(A R)$, descriptive geometry, engineering and computer graphics (DGECG)

(C) 2019 by the authors; licensee Modestum Ltd., UK. This article is an open access article distributed under the terms and conditions of the Creative Commons Attribution License (http://creativecommons.org/licenses/by/4.0/). \Voronina_MV@pers.spmi.ru $\boldsymbol{\square}$ Tretyakova_ZO@pers.spmi.ru (*Correspondence) $\square$ katrin1972@yandex.ru 凹bustivan@gmail.com \GGSidorenko@fa.ru 


\section{Contribution of this paper to the literature}

- a systematic analysis of qualitative and quantitative studies of AR-based educational courses has been proposed;

- it has been proved that AR issues in the training of DGECG students have not been sufficiently investigated in scientific and methodological literature;

- existing methods of teaching students are supplemented and updated by the method of graphical presentation of the results of creating an informational 3D-model of a building using AR-technologies.

\section{INTRODUCTION}

\section{The Urgency of the Problem}

In the modern situation of rapid design and growth of construction volumes, designers are facing new challenges. When presenting a construction project to a potential consumer, they have to deal with requirements which have never been made before. The use of modern augmented reality (AR) technologies in geometric building modeling has many advantages. Consequently, there is a need to teach students new construction design methods using AR technologies.

Along with the design, an important factor is the further presentation of the construction project to potential consumers. Augmented reality (AR) can be defined as a technology which overlays the real world with virtual objects (augmented components). Real objects are enhanced with computer-generated information, sometimes across multiple sensory modalities, including visual, auditory, haptic, somatosensory and olfactory (Augmented reality, 2019; Azuma, 1997; Azuma et al., 2001). The use of modern AR technologies provides us with a number of design tools, which can be used to complement the living, real world with digital models.

Thus, the need naturally has arisen for teaching students new design methods at construction sites using AR technologies, i.e. creating not just a project of a building being constructed in the form of drawings, mock-ups, working documentation, but a model containing all the information about the object, which can be in demand throughout the entire period of its existence - from design, then to operation, and finally to demolition or reconstruction. This model should be a full-fledged virtual copy of the building with its entire "contents" and infrastructure. Moreover, all data about the object should not only be grouped together, but be the parameters of the model, the correction of which, if necessary, entails the automatic change of the entire model. All these issues are being addressed by the new direction of design, which has relatively recently begun to be used in practice, information modeling of buildings and structures, as well as AR-technologies.

\section{Literature Review}

As it is known, AR was used for the first time for education purposes to train Boeing's airline pilots and Air Force pilots (Caudell \& Mizell, 1992). Although applications of that technology were limited primarily to an extended tracking technology, the authors of the article «Augmented Reality: An Application of Heads-Up Display Technology to Manual Manufacturing Processes» in the tutorial «Boeing Computer Services, Research and Technology» Thomas Caudell and David Mizell had already pointed out that «many near term applications are possible».

Despite the fact that:

- currently the AR-technology is used on every level of education: in school education (Billinghurst \& Duenser, 2012; Chiang, Yang, \& Hwang, 2014b; Kerawalla et al., 2006), at universities (Delello, McWhorter, \& Camp, 2015; Ferrer-Torregrosa et al., 2015);

- its use is not as difficult as it was in the past, as it no longer requires expensive hardware and sophisticated equipment;

- $\quad$ according to scientists, AR is currently considered as having potential for pedagogical applications, and much is known about the advantages of using AR in education (Burton et al., 2011; Chang, Morreale, \& Medicherla, 2010; Cheng \& Tsai, 2013; Coffin et al., 2008; Medina, Chen, \& Weghorst, 2008; Shelton \& Hedley, 2003; Singhal et al., 2012; Sumadio \& Rambli, 2010);

- compared to studies of other more mature education technologies (e.g., multimedia and web-based platforms), research of AR applications in education is at an early stage, and evidence of the effects of AR on teaching and learning appears to be shallow (Wu et al., 2013; Zarraonandia et al., 2013). In science education, research regarding AR-aided learning is in its infancy (Cheng \& Tsai, 2013), existing research has been inconsistent, 
driven largely by specific technical innovations and constraints, often lacking a clear focus on establishing their efficacy in educational contexts (Lindgren \& Johnson-Glenberg, 2013). Research is needed to ensure continuous enhancement of the implementation of this technology in the educational sector (Dalim et al., 2017).

\section{The Goals and Objectives of the Study}

The purpose of the study is to examine the current state of knowledge and practice of existing courses, which use the AR concept; to conduct a pedagogical experiment by teaching students how to create an information model of a building structure using the AR concept; to study the impact of the AR technology on students, on the quality of students' design works and project presentation. The main tasks were the following three:

- to discuss the effectiveness of the use of AR in teaching students DGECG, its advantages and disadvantages compared to traditional teaching method; research;

- to present recommendations by AR practitioners based on critical evaluation and synthesis of existing

- $\quad$ to investigate students' and teachers' attitude to this teaching model in general.

\section{MATERIALS AND METHODS}

To test the hypothesis of the study, a set of various complementing each other methods was used:

- theoretical: analysis of the teachers' and psychologists' works on the point of the research, analysis of methodological and educational literature; theoretical explanation of the possibility of introducing DGECG AR in engineering universities was given;

- empirical: observation, statement, pedagogical experiment, questioning, testing;

- $\quad$ experimental (stating, forming, control experiments); method of graphical representation of the results.

The experiment involved 168 first-year students and 26 teachers. The study was conducted in three stages:

- $\quad$ at the first stage, a theoretical analysis of existing methodological approaches in the scientific literature, dissertational works on problems, as well as theory and methodology of pedagogical research was carried out. The purpose, the methods of the research were determined, and the plan for experimental research was drawn up;

- $\quad$ at the second stage, experimental work was carried out, the results of the experimental work were analyzed, tested and clarified;

- $\quad$ at the third stage, the experimental work was completed, theoretical and practical conclusions were refined, the results obtained were summarized and systematized.

\section{Progress and Description of the Experiment}

\section{Systematic review of the literature}

Before the experiment on teaching students, a systematic review of the literature on the teaching methods used in educational institutions based on AR was conducted. More than 120 scientific articles were selected for analysis. When conducting a literature analysis, the following factors were considered: category of the educational institution and student, year of publication, academic discipline, AR technologies; the advantages and problems of using AR in educational institutions were considered.

\section{The formation of experimental groups of students. Setting a task}

In the course of the experiment, 168 first-year students were given the task to create an information model of a building.

The work was divided between three groups of students. The first group developed the building project in the traditional ways, the second group - using modern information technologies, the third group - consumer experts (customers) - estimated and compared the time spent, efforts, the results obtained and the perception of the final project. Existing methods of teaching students were supplemented and updated by the methods of graphical presentation of the results with due regard for AR-technologies.

\section{Stages of the students' work on creating an information model of the building}

1. At the first stage, primary design elements were developed that corresponded to both construction products (floor slabs, doors, windows, etc.), and equipment elements (heating and lighting devices, elevators, etc.) 
and everything that is directly related to the building, but is produced outside the construction site and during the construction of the object is not divided into parts.

2. The second stage was the modeling of everything that is created at the construction site. These are foundations, walls, roofs, curtain walls, etc. Thus, information modeling of a building initially implies having the understanding of how to erect this building, how to equip it and how to live and work in it. The division into stages (first and second) when creating the information model of the structure is not mandatory - for instance, it's possible to insert windows into the simulated objects, and then change them, and the already changed windows will appear in the project.

3. At the third stage, a virtual building model was created.

\section{Problem Status}

- Currently, AR-technologies are used at all levels of education: at schools, at universities.

- Using AR at our time is not as difficult as it was in the past, since it no longer requires expensive and complex equipment.

- $\quad$ AR is currently considered to have potential for pedagogical application and much is known about the benefits of $A R$ in education

- $\quad$ There is not much evidence of the impact of AR on teaching and learning. In the field of science education, research in the field of AR-enhanced learning is in its infancy.

- Existing studies are fragmented, mainly due to specific technical innovations and limitations, often do not have a clear focus on establishing their effectiveness in the educational context, and further research is needed to ensure continuous improvement and more efficient introduction of this technology in the educational sector.

\section{RESULTS}

\section{A Systematic Analysis of Studies of AR-Based Educational Courses}

Tables 1-5 present some research conducted on AR in different fields of education. The analysis includes examples of how the AR technology was implemented in the respective fields of education, namely, Medicine, Chemistry, Mathematics, Physics, Biology, Astronomy and History. This research was conducted in order to evaluate the potential of AR in education.

Table 1. AR in different fields of preschool and school education

\begin{tabular}{|c|c|c|c|c|}
\hline № & Year & Academic discipline & Authors & Article title \\
\hline 1 & 2003 & $\begin{array}{l}\text { Mathematics and } \\
\text { geometry }\end{array}$ & $\begin{array}{l}\text { H. Kaufmann \& D. Schmalstieg } \\
(2003)\end{array}$ & $\begin{array}{l}\text { Mathematics and geometry education with collaborative augmented } \\
\text { reality }\end{array}$ \\
\hline 2 & 2006 & Primary school science & $\begin{array}{l}\text { L. Kerawalla, R. Luckin, S. } \\
\text { Seljeflot \& A. Woolard (2006) }\end{array}$ & $\begin{array}{l}\text { «Making it real»: exploring the potential of augmented reality for } \\
\text { teaching primary school science }\end{array}$ \\
\hline 3 & 2006 & Chemistry & Y.-C. Chen (2006) & $\begin{array}{l}\text { A study of comparing the use of augmented reality and physical } \\
\text { models in chemistry education }\end{array}$ \\
\hline 4 & 2008 & Physics & $\begin{array}{l}\text { S.A. Sotiriou \& F.X. Bogner } \\
(2008)\end{array}$ & $\begin{array}{l}\text { Visualizing the invisible: Augmented reality as an innovative science } \\
\text { education scheme }\end{array}$ \\
\hline 5 & 2009 & & C.J. Dede (2009) & Immersive interfaces for engagement and learning \\
\hline 6 & 2010 & Building & L. Simeone \& S. Iaconesi (2010) & Toys ++ AR embodied agents as tools to learn by building \\
\hline 7 & 2010 & Environment & $\begin{array}{l}\text { W. Chang, Q. Tan \& F.W. Tao } \\
(2010)\end{array}$ & $\begin{array}{l}\text { Multi-object-oriented augmented reality for location-based adaptive } \\
\text { mobile learning }\end{array}$ \\
\hline 8 & 2010 & $\begin{array}{l}\text { Anatomy (digestive } \\
\text { and circulatory } \\
\text { systems) }\end{array}$ & $\begin{array}{l}\text { D. Pérez-López, M. Contero \& } \\
\text { M. Alcãiz (2010) }\end{array}$ & $\begin{array}{l}\text { Collaborative development of an augmented reality application for } \\
\text { digestive and circulatory systems teaching }\end{array}$ \\
\hline 9 & 2011 & $10-17$ ages & $\begin{array}{l}\text { N.A.M. El Sayed, H.H. Zayed \& } \\
\text { M.I. Sharawy (2011) }\end{array}$ & ARSC: Augmented reality student card \\
\hline 10 & 2011 & $\begin{array}{l}\text { Conservation of fish in } \\
\text { Taiwan }\end{array}$ & $\begin{array}{l}\text { H.-C.K. Lin, M.-C. Hsieh, C.-H. } \\
\text { Wang, Z.-Y. Sie \& S.-H. Chang } \\
(2011)\end{array}$ & $\begin{array}{l}\text { Establishment and usability evaluation of an interactive AR learning } \\
\text { system on conservation of fish }\end{array}$ \\
\hline 11 & 2011 & Physics & J. Gu, N. Li \& H.B.L. Duh (2011) & A remote mobile collaborative AR system for learning in physics \\
\hline 12 & 2012 & Elementar & C.-M. Chen \& Y.-N. Tsai (2012) & $\begin{array}{l}\text { Interactive augmented reality system for enhancing library instruction } \\
\text { in elementary schools }\end{array}$ \\
\hline
\end{tabular}


Table 1 (continued). AR in different fields of preschool and school education

\section{№ Year Academic discipline Authors}

132012 Science museum

152012 Astronomy

162012 Insect (butterfly)

172012 Secondary schools

182012 Geometric shapes

192013 Art

S.A. Yoon, K. Elinich, J. Wang, C. Steinmeier \& S. Tucker (2012) K.-F. Hsiao, N.-S. Chen \& S.-Y. Huang (2012) K. Kinshuk \& C.-Y. Chen (2012) W. Tarng \& K.-L. Ou (2012)

M. Davidsson, D. Johansson \& K. Lindwall (2012)

T.G. Kirner, F.M. Reis, V. \& C. Kirner (2012)

A. Di Serio, M.B. Ibanez \& C.D. Kloos (2013)

202013 Urban middle school D. Bressler \& A. Bodzin (2013)

AM. Kamarainen, S. Metcalf, T.

212013 Pond environment Grotzer, A. Browne, D. Mazzuca M.S. Tutwiler \& K. Dede (2013)

\begin{tabular}{ll}
\hline 222013 Physics & Cai, Chiang \& Wang (2013) \\
\hline 232014 Astronomy & $\begin{array}{l}\text { J. Zhang, Y.-T. Sung, H.-T. Hou, \& } \\
\text { K.-E. Chang (2014) }\end{array}$ \\
\hline 242014 Art & $\begin{array}{l}\text { K.-E. Chang, C.-T. Chang, H.-T. } \\
\text { Hou, Y.-T. Sung, H.-L. Chao, \& C.- } \\
\text { M. Lee (2014) }\end{array}$ \\
\hline 252014 Natural science & $\begin{array}{l}\text { T.H.C. Chiang, S.J.H. Yang \& G. } \\
\text { Hwang (2014a) }\end{array}$ \\
\hline 262014 Chemistry & $\begin{array}{l}\text { S. Cai, X. Wang \& F.K. Chiang } \\
\text { (2014) }\end{array}$ \\
\hline 272015 Young children & $\begin{array}{l}\text { J. Han, M. Jo, E. Hyun \& H.-J. So } \\
\text { (2015) }\end{array}$ \\
\hline 282015 Marine education & \begin{tabular}{l} 
S.-J. Lu \& Y.-C. Liu (2015) \\
\hline
\end{tabular}
\end{tabular}

J.A. Munoz-Cristobal, I.M. Jorrin-

292015 Primary education Abellan, J.I. Asensio-Perez, A. Supporting teacher orchestration in ubiquitous learning Martinez-Mones, L.P. Prieto \& Y. environments: A study in primary education Dimitriadis (2015)

\begin{tabular}{|c|c|c|c|c|}
\hline 30 & 2015 & Solid geometry & $\begin{array}{l}\text { H.-C.K. Lin, M.-C. Chen, \& C.-K. } \\
\text { Chang (2015) }\end{array}$ & $\begin{array}{l}\text { Assessing the effectiveness of learning solid geometry by using an } \\
\text { augmented reality-assisted learning system }\end{array}$ \\
\hline 31 & 2016 & Reading & K.-H. Cheng \& C.-C. Tsai (2016) & $\begin{array}{l}\text { The interaction of child-parent shared reading with an augmented } \\
\text { reality (AR) picture book and parents' conceptions of AR learning }\end{array}$ \\
\hline 32 & 2016 & Art & Y.Li.H. Huang \& R. Fong (2016) & $\begin{array}{l}\text { Using augmented reality in early art education: A case study in Hong } \\
\text { Kong kindergarten. Early Child Development and Care }\end{array}$ \\
\hline 33 & 2017 & $\begin{array}{l}\text { Software editing } \\
\text { course }\end{array}$ & Y.H. Wang (2017) & $\begin{array}{l}\text { Using augmented reality to support a software editing course for } \\
\text { college students }\end{array}$ \\
\hline 34 & 2017 & Writing & Y.H. Wang (2017) & $\begin{array}{l}\text { Exploring the Effectiveness of Integrating Augmented Reality-Based } \\
\text { Materials to Support Writing Activities }\end{array}$ \\
\hline 35 & 2017 & English & Hsu (2017) & Learning English with augmented reality: Do learning styles matter? \\
\hline 36 & 2017 & $\begin{array}{l}\text { Geometric objects } \\
\text { and measuring } \\
\text { volume }\end{array}$ & E.T. Gün \& B. Atasoy (2017) & $\begin{array}{l}\text { The effects of augmented reality on elementary school students' } \\
\text { spatial ability and academic achievement }\end{array}$ \\
\hline 37 & 2017 & $\begin{array}{l}\text { Pedestrian } \\
\text { navigation }\end{array}$ & $\begin{array}{l}\text { J. Joo-Nagata, F.M. Abad, J.G.B. } \\
\text { Giner \& F.J. García-Peñalvo } \\
\text { (2017) }\end{array}$ & $\begin{array}{l}\text { Augmented reality and pedestrian navigation through its } \\
\text { implementation in m-learning and e-learning: Evaluation of an } \\
\text { educational program in Chile }\end{array}$ \\
\hline 38 & 2017 & English alphabet & $\begin{array}{l}\text { A.H. Safar, A.A. Al-Jafar \& Z.H. Al- } \\
\text { Yousefi (2017) }\end{array}$ & $\begin{array}{l}\text { The effectiveness of using augmented reality apps in teaching the } \\
\text { English alphabet to kindergarten children: A case study in the State of } \\
\text { Kuwait }\end{array}$ \\
\hline 39 & 2017 & $5-6$ ages & $\begin{array}{l}\text { R. Yilmaz \& S. Kucuk \& Y. Goktas } \\
\text { (2017) }\end{array}$ & $\begin{array}{l}\text { Are augmented reality picture books magic or real for preschool } \\
\text { children aged five to six? }\end{array}$ \\
\hline
\end{tabular}

\section{Article title}

improve learning in a science museum

among adolescents

A context-aware ubiquitous learning approach to conducting scientific inquiry activities in a science park

A study of campus butterfly ecology learning system based on augmented reality and mobile learning

\section{in secondary schools}

Development of an interactive book with Augmented Reality for teaching and learning geometric shapes

Impact of an augmented reality system on students' motivation for a visual art course.

A mixed methods assessment of students' flow experiences during a mobile augmented reality science game

ECOMOBILE: Integrating augmented reality and probe ware with environmental education field trips

Using the augmented reality 3D technique for a convex imaging experiment in a physics course

The development and evaluation of an augmented reality-based armillary sphere for astronomical observation instruction

Development and behavioral pattern analysis of a mobile guide system with augmented reality for painting appreciation instruction in an art museum

An Augmented Reality-based mobile learning system to improve students' learning achievements and motivations in natural science inquiry activities

A case study of augmented reality simulation system application in a chemistry course

Examining young children's perception toward augmented realityinfused dramatic play

Integrating augmented reality technology to enhance children's learning in marine education

Assessing the effectiveness of learning solid geometry by using an

reality (AR) picture book and parents' conceptions of AR learning

dy in Hong college students Materials to Support Writing Activities Augmented reality and pedestrian navigation through its educational program in Chile

English alphabet to kindergarten children: A case study in the State of children aged five to six?
The effects of augmented reality on elementary school students' 
Table 2. AR in different fields of university education

\begin{tabular}{|c|c|c|c|c|}
\hline № & Year & Academic discipline & Authors & Article title \\
\hline 1 & 2002 & Astronomy & B.E. Shelton \& N.R. Hedley (2002) & $\begin{array}{l}\text { Using augmented reality for teaching earth-sun } \\
\text { relationship to undergraduate geography students }\end{array}$ \\
\hline 2 & 2006 & Guitar playing & Y. Motokawa, \& H. Saito (2006) & $\begin{array}{l}\text { Support system for guitar playing using augmented } \\
\text { reality display }\end{array}$ \\
\hline 3 & 2007 & $\begin{array}{l}\text { Environmental } \\
\text { engineering education }\end{array}$ & K.D. Squire, \& E. Klopfer (2007) & Augmented reality simulations on handheld computers \\
\hline 4 & 2007 & $\begin{array}{l}\text { Environmental } \\
\text { engineering education }\end{array}$ & K.D. Squire, \& M. Jan (2007) & $\begin{array}{l}\text { Mad City Mystery: Developing scientific argumentation } \\
\text { skills with a place-based augmented reality game on } \\
\text { handheld computers }\end{array}$ \\
\hline 5 & 2008 & Biochemistry & E. Medina, Y.-C. Chen, \& S. Weghorst (2008) & Understanding biochemistry with augmented reality \\
\hline 6 & 2009 & Magnetism & $\begin{array}{l}\text { S. Matsutomo, T. Miyauchi, Noguchi, \& S.H. } \\
\text { Yamashita (2009) }\end{array}$ & $\begin{array}{l}\text { Realtime visualization system of magnetic field utilizing } \\
\text { augmented reality technology for education }\end{array}$ \\
\hline 7 & 2010 & Live Solar System & A.K. Sin \& B.Z. Halimah (2010) & $\begin{array}{l}\text { Live Solar System (LSS): Evaluation of an Augmented } \\
\text { Reality book-based educational tool }\end{array}$ \\
\hline 8 & 2010 & $\begin{array}{l}\text { Mechanical } \\
\text { engineering }\end{array}$ & $\begin{array}{l}\text { J. Martín-Gutiérrez, , J. L. Saorín, M. Contero, } \\
\text { M. Alcañiz, D.C. Pérez-López, \& M. Ortega } \\
\text { (2010) }\end{array}$ & $\begin{array}{l}\text { Design and validation of an augmented book for spatial } \\
\text { abilities development in engineering students }\end{array}$ \\
\hline 9 & 2011 & Anthropology & L. Simeone \& S. laconesi (2011) & $\begin{array}{l}\text { Anthropological conversations: Augmented reality } \\
\text { enhanced artifacts to foster education in cultural } \\
\text { anthropology }\end{array}$ \\
\hline 10 & 2011 & English & $\begin{array}{l}\text { Y.-J. Chang, C.-H. Chen, W.-T. Huang, \& W. } \\
\text { Huang (2011) }\end{array}$ & $\begin{array}{l}\text { Investigating students' perceived satisfaction, behavioral } \\
\text { intention, and effectiveness of english learning using } \\
\text { augmented reality }\end{array}$ \\
\hline 11 & 2012 & Chemistry & $\begin{array}{l}\text { S. Singhal, S. Bagga, P. Goyal \& V. Saxena } \\
\text { (2012) }\end{array}$ & Augmented chemistry: interactive education system \\
\hline 12 & 2012 & Anatomy & $\begin{array}{l}\text { T. Blum, V. Kleeberger, C. Bichlmeier \& N. } \\
\text { Navab (2012) }\end{array}$ & $\begin{array}{l}\text { Mirracle: an augmented reality magic mirror system for } \\
\text { anatomy education }\end{array}$ \\
\hline 13 & 2012 & $\begin{array}{l}\text { Physical education } \\
(\mathrm{PE})\end{array}$ & K.-F. Hsiao (2012) & $\begin{array}{l}\text { Using augmented reality for students healthcase of } \\
\text { combining educational learning with standard fitness }\end{array}$ \\
\hline 14 & 2012 & engineering labs & $\begin{array}{l}\text { S. Odeh, S.A. Shanab, M. Anabtawi \& R. } \\
\text { Hodrob (2012) }\end{array}$ & Remote augmented reality engineering labs \\
\hline 15 & 2012 & Chemistry & $\begin{array}{l}\text { S. Singhal, S. Bagga, P. Goyal, \& V. Saxena } \\
\text { (2012) }\end{array}$ & Augmented chemistry: interactive education system. \\
\hline 16 & 2014 & Construction & S. Kiryakidi (2014) & $\begin{array}{l}\text { Augmented reality and the prospects for its use in the } \\
\text { construction industry }\end{array}$ \\
\hline 17 & 2014 & Math & P. Sommerauer, \& O. Müller (2014) & $\begin{array}{l}\text { Augmented reality in informal learning environments: A } \\
\text { field experiment in a mathematics exhibition }\end{array}$ \\
\hline 18 & 2014 & Electromagnetism & $\begin{array}{l}\text { M.B. Ibáñez, A. Di Serio, D. Villarán \& C.D. } \\
\text { Kloos (2014) }\end{array}$ & $\begin{array}{l}\text { Experimenting with electromagnetism using augmented } \\
\text { reality: Impact on flow student experience and } \\
\text { educational effectiveness }\end{array}$ \\
\hline 19 & 2015 & $\begin{array}{l}\text { Industrial } \\
\text { maintenance and } \\
\text { assembly }\end{array}$ & $\begin{array}{l}\text { N. Gavish, T. Gutierrez, S. Webel, J. } \\
\text { Rodríguez, M. Peveri, U. Bockholt \& F. } \\
\text { Tecchia (2015) }\end{array}$ & $\begin{array}{l}\text { Evaluating virtual reality and augmented reality training } \\
\text { for industrial maintenance and assembly tasks }\end{array}$ \\
\hline 20 & 2015 & Anatomy & $\begin{array}{l}\text { J. Ferrer-Torregrosa, J. Torralba, M.A. } \\
\text { Jimenez, S. García \& J.M. Barcia (2015) }\end{array}$ & $\begin{array}{l}\text { ARBOOK: Development and assessment of a tool based } \\
\text { on augmented reality for Anatomy }\end{array}$ \\
\hline 21 & 2015 & $\begin{array}{l}\text { Technical creative } \\
\text { design course }\end{array}$ & X. Wei, D. Weng, Y. Liu \& Y. Wang (2015) & $\begin{array}{l}\text { Teaching based on augmented reality for a technical } \\
\text { creative design course }\end{array}$ \\
\hline 22 & 2016 & Dental morphology & M. Juan (2016) & $\begin{array}{l}\text { M.A Juan mobile augmented reality system for the } \\
\text { learning of dental morphology }\end{array}$ \\
\hline 23 & 2017 & Math & P. Salinas \& R. Pulido (2017) & Understanding the conics through augmented reality \\
\hline 24 & 2018 & Chemistry & 2018) & $\begin{array}{l}\text { Mobile augmented reality assisted chemical education: } \\
\text { insights from elements 4D }\end{array}$ \\
\hline
\end{tabular}


Table 3. AR in special directions of education

\section{№ Year Academic discipline Authors}

Science education for T.N. Arvanitis, A. Petrou, J.F.

2009 learners with physical Knight, S. Savas, S. Sotiriou, M.

disabilities

Musical system for children

22009 with cerebral palsy rehabilitation

32010 Book for deaf students

42015 ICT for the elderly Physical activities for

52015 children with developmental C.Y. Lin \& Y.M. Chang (2015) disabilities

Gargalakos \& E. Gialouri (2009)

A.G.D. Corrêa, I.K. Ficheman, M. Nascimento \& R. Lopes (2009)

N.M.M. Zainuddin, H.Z. Badioze Zaman \& A. Ahmad (2010)

R. Saracchini, , C. Catalina \& L. Bordoni (2015)

For students with intellectual D.D. McMahon, D.F. Cihak, R.E.

62016 disabilities and autism $\quad$ Wright \& S.M. Bell (2016)

\section{Article title}

Human factors and qualitative pedagogical evaluation of a mobile augmented reality system for science education used by learners with physical disabilities

Computer assisted music therapy: a case study of an augmented reality musical system for children with cerebral palsy rehabilitation

A participatory design in developing prototype an Augmented Reality book for deaf students

A mobile augmented reality assistive technology for the elderly

Interactive augmented reality using Scratch 2.0 to improve physical activities for children with developmental disabilities

Augmented reality for teaching science vocabulary to postsecondary education students with intellectual disabilities and autism

Table 4. Reviews of AR applications in education

\section{№ Year Authors}

Article title

12009 M. Dunleavy, C. Dede \& R. Mitchell (2009)

Affordances and limitations of immersive participatory augmented reality simulations for teaching and learning

22009 D. Yu, J.S. Jin, S. Luo, W. Lai \& Q. Huang (2009)

A useful visualization technique: A literature review for augmented reality and its

22009 D. Yu, J.S. Jin, S. Luo, W. Lai \& Q. Huang (2009) application, limitation \& future direction

32010 R.S. Davies, S.L. Howell \& J.A. Petrie (2010) A review of trends in distance education scholarship at research universities in North

America,

42011 S.C. Bronack (2011) The role of immersive media in online education

52011 G.-J. Hwang \& C.-C. Tsai (2011) Research trends in mobile and ubiquitous learning: A review of publications in

52011 G.-J. Hwang \& C.-C. Tsai (2011) selected journals from 2001 to 2010

$62012 \begin{aligned} & \text { W.-H. Wu, Y.-C.J. Wu, C.-Y. Chen, H.-Y. Kao, C.- } \\ & \text { H. Lin \& S.-H. Huang (2012) }\end{aligned}$

$72012 \quad$ Why should my students use AR? A comparative review of the educational impacts of

$82013 \begin{aligned} & \text { H.-K. Wu, S. W.-Y., Lee, H.-Y. Chang \& J.-C. } \\ & \text { Liang (2013) }\end{aligned}$

92013 P.H.E. Liu \& M.K. Tsai (2013) augmented-reality

Current status, opportunities and challenges of augmented reality in education

102014 M. Antonioli, C. Blake \& K. Sparks (2014) Using augmented-reality-based mobile learning material in EFL English composition: An exploratory case study

112014 J. Bacca, S. Baldiris, R. Fabregat, \& S. Graf Augmented reality applications in education

122014 M.E.C. Santos, A. Chen, , T. Taketomi, G. Augmented reality trends in education: A systematic review of research and applications

122014 Yamamoto, J. Miyazaki \& H. Kato (2014) 132014 I. Radu (2014)

142014 J.M. Martin-Gutiérrez \& M.D.M. Fernandez \begin{tabular}{lll}
$14 \quad 2014 \quad(2014)$ \\
\hline
\end{tabular} Augmented reality learning experiences: Survey of prototype design and evaluation

152015 Y.-L. Chang, H.-T. Hou, C.-Y. Pan, Y.-T. Sung \& K.-E. Chang (2015)

162015 N.F. Saidin, N.D. Abd Halim \& N.N Yahaya A Review of Research on Augmented Reality in Education: Advantages and

$16 \quad 2015 \quad(2015)$

172015 J.A. Delello, R.R. McWhorter \& K.M. Camp (2015)

182016 G. Akçayır \& M. Akçayır (2016)

192016 Tekederea, H. \& Göke, H. (2016)

202017 C.S.C. Dalim, H. Kolivand, H. Kadhim, M.S.

2017 Sunar \& M. Billinghurst (2017)

212017 J. Li, E. Spek, L. Feijs, F. Wang \& J. Hu (2017)

222017 Y.H. Hung, C.H. Chen \& S.W. Huang (2017)

232017 M. Akçayır \& G. Akçayır (2017) Augmented reality in education: a meta-review and cross-media analysis Applying augmented reality in engineering education to improve academic performance \& student motivation

Apply an augmented reality in a mobile guidance to increase sense of place for heritage places Applications International Education Studies Integrating augmented reality in higher education: a multidisciplinary study of student perceptions Research trends in social network sites' educational use

Examining the Effectiveness of Augmented Reality Applications in Education: A MetaAnalysis

Factors Influencing the Acceptance of Augmented Reality in Education

Augmented Reality Games for Learning: A Literature Review

Applying augmented reality to enhance learning: A study of different teaching materials

Advantages and challenges associated with augmented reality for education: A systematic review of the literature.

242018 J. Garzón, J. Pavón \& S. Baldiris (2018) Systematic review and meta-analysis of augmented reality in educational settings

252018 N. Pellas, P. Fotaris, I. Kazanidis \& D. Wells (2018)

262018 M. Sırakaya \& D. Alsancak Sırakaya (2018)

272018 R.M. Yilmaz (2018) Augmenting the learning experience in primary and secondary school education: a systematic review of recent trends in augmented reality game-based learning Trends in Educational Augmented Reality Studies: A Systematic Review Augmented Reality Trends in Education between 2016 and 2017 Years, State of the Art Virtual Reality and Augmented Reality Knowhow 
Table 5. AR in Descriptive Geometry

\begin{tabular}{|c|c|c|c|}
\hline № & Year & Authors & Article title \\
\hline 1 & 2005 & $\begin{array}{l}\text { H. Kaufmann, K. Steinbügl, A. Dünser \& J. Glück } \\
(2005)\end{array}$ & $\begin{array}{l}\text { General training of spatial abilities by geometry education in Augmented } \\
\text { Reality }\end{array}$ \\
\hline 2 & 2006 & H. Kaufmann (2006) & The potential of augmented reality in dynamic geometry education. \\
\hline 3 & 2011 & $\begin{array}{l}\text { H. Chen, K. Feng, C. Mo, S. Cheng, Z. Guo \& Y. } \\
\text { Huang (2011) }\end{array}$ & Application of Augmented Reality in Engineering Graphics education \\
\hline 4 & 2013 & $\begin{array}{l}\text { J. Martin-Gutiérrez, M. García-Domínguez, C. } \\
\text { Roca-González, A. Sanjuán-HernanPérez \& C. } \\
\text { Mato-Carrodeguas (2013) }\end{array}$ & $\begin{array}{l}\text { Comparative analysis between training tools in spatial skills for Engineering } \\
\text { Graphics students based in Virtual Reality, Augmented Reality and PDF3D } \\
\text { Technologies }\end{array}$ \\
\hline 5 & 2014 & Z. Veide, V. Stroževa \& M. Dobelis (2014) & $\begin{array}{l}\text { Application of Augmented Reality for teaching Descriptive Geometry and } \\
\text { Engineering Graphics course to first-year students }\end{array}$ \\
\hline 6 & 2015 & N. Argelia Aguilera González (2015) & How to include Augmented Reality in Descriptive Geometry Teaching \\
\hline 7 & 2016 & $\begin{array}{l}\text { E. Gutiérrez de Ravé, F. Jiménez-Hornero, A. } \\
\text { Ariza Villaverde \& J.Taguas-Ruiz (2016) }\end{array}$ & Mobile augmented reality system applies to Descriptive Geometry learning \\
\hline 8 & 2016 & $\begin{array}{l}\text { J.deF. Pires, L.D. Vecchia, \& A.A.daS Borda } \\
(2016)\end{array}$ & $\begin{array}{l}\text { Transiting between representation technologies and teaching/learning } \\
\text { Descriptive Geometry: reflections in an architectural context }\end{array}$ \\
\hline 9 & 2017 & $\begin{array}{l}\text { A. Cascales-Martínez, M.J. Martínez-Segura, D. } \\
\text { Pérez-López \& M. Contero (2017) }\end{array}$ & $\begin{array}{l}\text { Using an augmented reality enhanced tabletop system to promote learning } \\
\text { of mathematics: A case study with students with special educational needs }\end{array}$ \\
\hline
\end{tabular}

\section{Experiment}

After reviewing the problem being studied - teaching students with the help of the AR technology - an experiment was conducted to introduce this technology to the educational process (Tretyakova \& Merkulova, 2017; Tretyakova et. al., 2018; Tretyakova, Merkulova, \& Voronina, 2018). In the course of this experiment, 168 first-year students were given the task to create an informational model of a building.

The work was divided between three groups of students. The first group developed the building project in the traditional ways, the second group - using modern information technologies, the third group - consumer experts (customers) - estimated and compared the time spent, efforts, the results obtained and the perception of the final project. Existing methods of teaching students were supplemented and updated by the methods of graphical presentation of the results with due regard for AR-technologies.

Stages of the Students' Work on Creating an Information Model of the Building

1. At the first stage, primary design elements were developed that corresponded to both construction products (floor slabs, doors, windows, etc.), and equipment elements (heating and lighting devices, elevators, etc.) and everything that is directly related to the building, but is produced outside the construction site and during the construction of the object is not divided into parts.

2. The second stage was the modeling of everything that is created at the construction site. These are foundations, walls, roofs, curtain walls, etc. Thus, information modeling of a building initially implies having the understanding of how to erect this building, how to equip it and how to live and work in it. The division into stages (first and second) when creating the information model of the structure is not mandatory - for instance, it's possible to insert windows into the simulated objects, and then change them, and the already changed windows will appear in the project.

3. At the third stage, a virtual building model was created. 


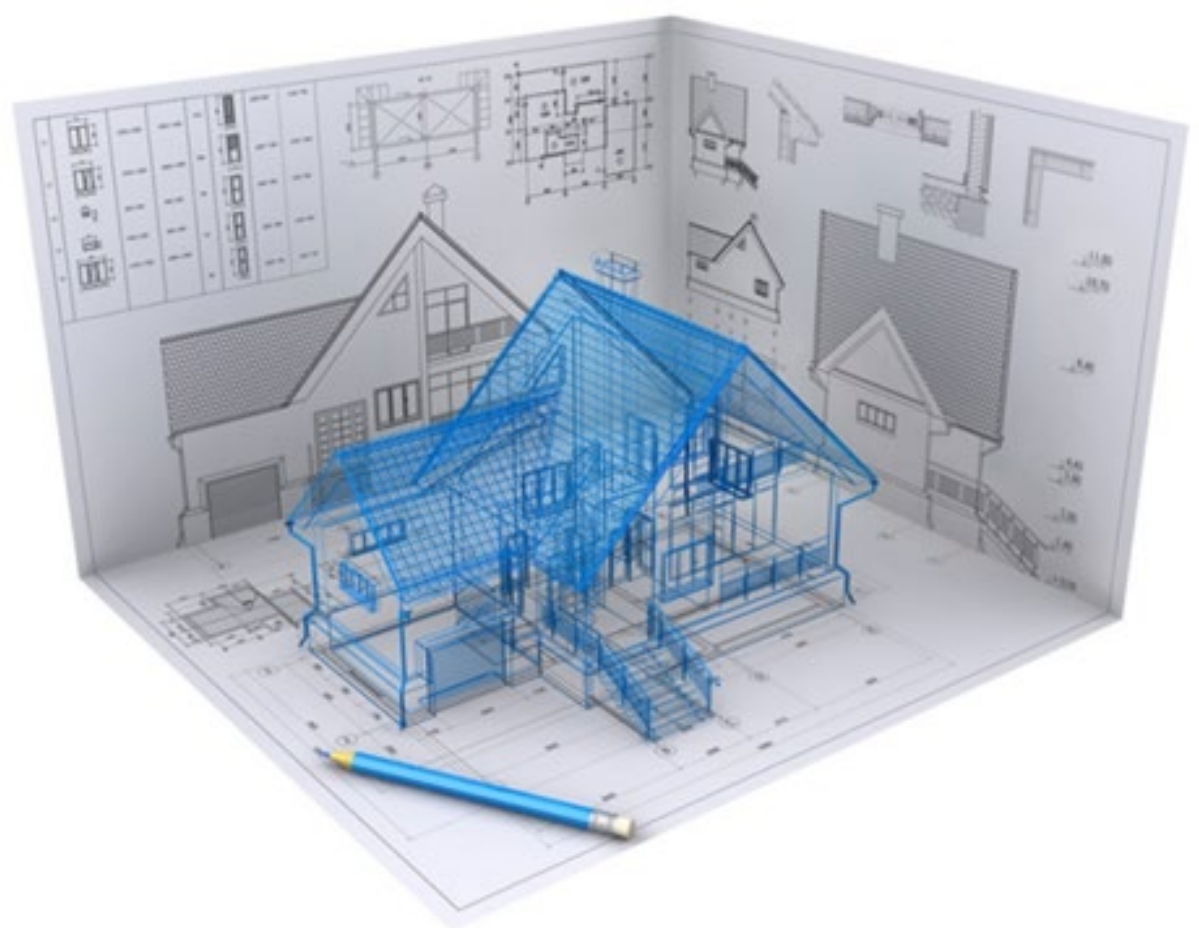

Figure 1. Creation of an informational model of a building

Using new technologies and uniting all the stages of project development allows for the reduction of time spent on the project thanks to the interconnection of the previously separate stages. The work of different specialists such as an architect, planner, communication engineer or designer is now constantly linked.

As a visualisation AR-tool a software package can be used; such a package would consist of the following elements:

1. An application for portable devices such as a phone, tablet, laptop or PC. To run this application the device must have a camera, internet access and the appropriate OS and hardware.

2. Software allowing work with databases and QR-codes (adding and removing objects, QR-code generation, marker printing). It must be noted that any free service can be used for code generation. A QR-code is a code containing an encrypted identifier which corresponds to a specific operation.

This way, an informational model of a building has been created which allows the viewer to 'get inside the structure' and examine all its elements in detail (Figure 2).
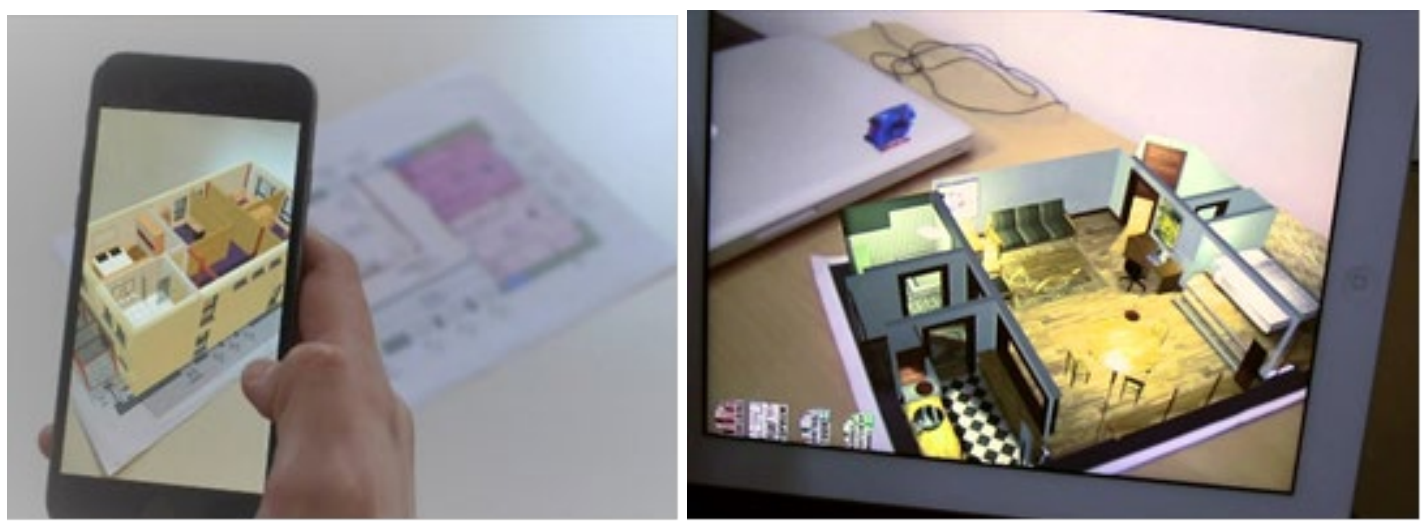

Figure 2. Informational model of a building

To carry out a similar project using traditional methods would be much more time- and energy-consuming. What's more, the final result would be much less informative for the consumers who do not possess even basic knowledge of building design; all the conventional signs and markers seen in the model as well as the importance of constructive elements have to be understandable for the end user. 


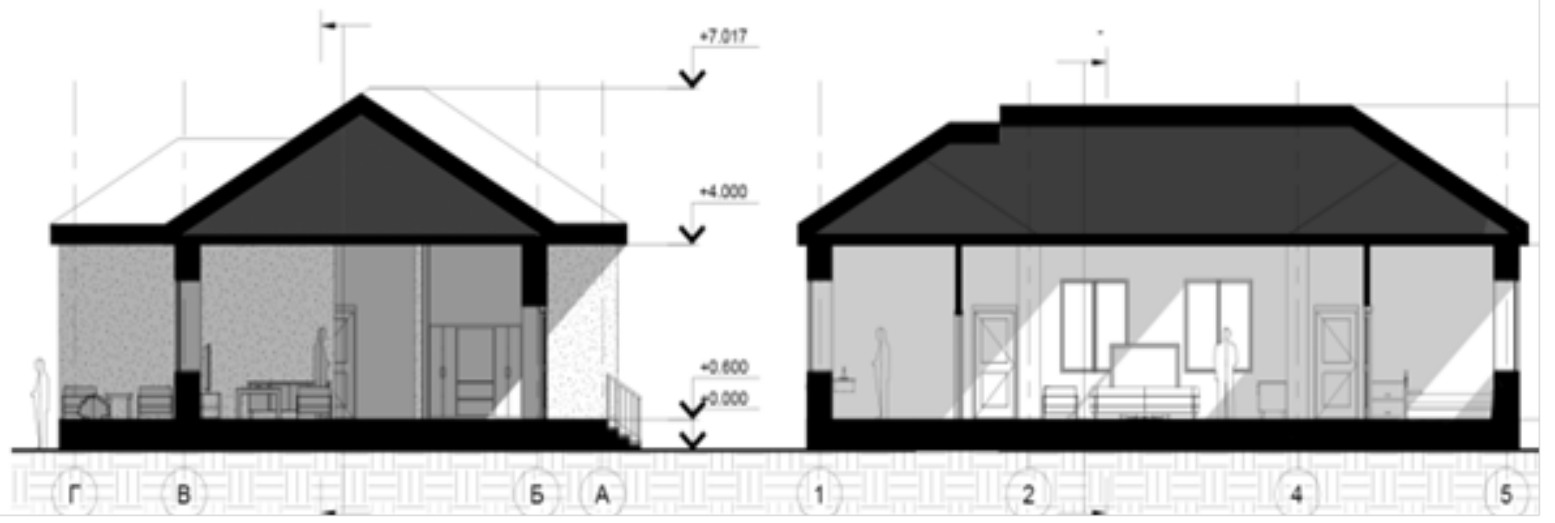

Figure 3. Project created using traditional methods

\section{DISCUSSION}

The third group of students, acting as customers, estimated the perception of the project. In their opinion, the informational model of the building created with the help of modern computer technologies allows for a fuller view of the structure. What's more, from the consumer's point of view such a presentation is more graphic, as it's usually quite challenging for them to understand details of the drawing.

The design process always depends on the interests of two groups of people: planners and consumers. Each group aspires to have their requirements met, which can sometimes cause controversy. And the project authors inevitably face the problem of choosing the final variant of the design.

Having created a few 3D models using AR-software, it's possible to show the possible options to the customer and begin negotiations at the very first meeting. Several cards with bindings can make solving technical problem much easier and quicken the discussion, as AR allows for an immediate transformation of an idea into a visual model. At the moment it is only a prototype on the building market, but it will give a company the chance to stand out while keeping its expenses to a minimum. It is also possible to use AR at the construction site itself to specify some moments concerning the position of the building on the plot. Designing the plot at the initial stage is made significantly less difficult by the clearness of the work and also the ability to do it online (Augmented Reality: Mobile Architectural Applications of the Future, 2015).

The AR technology gives designers the opportunity to follow the stages of the building project and compare the real object with its model. This way, people who are unfamiliar with the building sphere can without much effort control building erection.

$\mathrm{AR}$ is absolutely irreplaceable for finishing work as its use reduces not only the amount of time spent on building the structure, but also the probability of builders making a mistake; it also prevents arguments arising between the customer and the developer because of misunderstanding.

The main advantage of AR is the absence of the necessity to use any additional resources. For example, compared to VR-objects (which require a significant amount of additional hardware such as VR-glasses or helmets to be shown), AR-drawings can be seen on the screen of a usual phone or tablet, now owned by almost everyone.

\section{CONCLUSION}

The team of students successfully carried out the task of designing a building using AR and created an informational model of this building. Based on the research conducted by the students, their teachers gave recommendations concerning their further education. However, despite the obviousness of the need to teach AR and its application to designing buildings and structures to the new generation of students, this research has shown that there is still no well-tested curriculum, as well as teaching materials, when it comes to the use of AR.

It's worth saying that teachers do not have to base their classes exclusively on AR technologies, but the latter have to become part of the lesson, providing additional visual support.

Besides, learning a subject takes more than simply acquiring theoretical knowledge. It's impossible to limit students' work to attending lectures and checking graphic materials. Students, especially those who want to become technical specialists, have to be taught practical skills and get professional experience. Sometimes acquiring such skills at university is not feasible, therefore laboratories equipped with AR hard- and software can provide future graduates with at least visual skills. 
The main advantage of AR is that it visualizes difficult to imagine objects by turning them into 3D models, which facilitates students' understanding of abstract and complex information. Its users can choose the color, transparency, angle etc. This approach is especially useful for improving students' abstract thinking and for people who work on transforming theoretical material into real projects.

Despite being actively used in many spheres of modern life, AR as a tool of modernizing education is still a matter open for discussion.

Which leads to the conclusion that it is necessary to:

- $\quad$ create a theoretical base in teaching DGECG with the help of AR and assessing students' progress.

- $\quad$ carry out further research studying various aspects of practical realization of long-term, well-tested programs and teaching materials in teaching AR to DGECG students.

\section{RECOMMENDATIONS}

This article could be found useful by teachers of technical subjects who aspire to increases their students' understanding of the information they are given in class.

We see the presented model of facilitating students' learning as a perspective direction which should be further developed and introduced to the curriculums of various educational institutions.

\section{ACKNOWLEDGEMENTS}

The study was carried out with the support of the Grant of The Ministry of Education and Science of the Russian Federation "Teacher Training Technologies in a Classical University Environment", the project № 27.9412.2017/БЧ.

\section{REFERENCES}

Akçayır, G., \& Akçayır, M. (2016). Research trends in social network sites' educational use: A review of publications in all SSCI journals to 2015. Review of Education, 4(3), 293-319. https:/ / doi.org/10.1002/ rev3.3075

Akçayır, M., \& Akçayır, G. (2017). Advantages and challenges associated with augmented reality for education: A systematic review of the literature. Educational Research Review, 20, 453-461. https:// doi.org/10.1016/j.edurev.2016.11.002

Antonioli. M., Blake, C., \& Sparks, K. (2014) Augmented reality applications in education. The Journal of Technology Studies, 40(1), 96-107. https:/ / doi.org/10.21061/jots.v40i2.a.4

Argelia Aguilera González, N. (2015). How to Include Augmented Reality in Descriptive Geometry Teaching. Procedia Computer Science, 75, 250-256. https:/ / doi.org/10.1016/j.procs.2015.12.245

Arvanitis, T. N., Petrou, A., Knight, J. F., Savas, S., Sotiriou, S., Gargalakos, M., \& Gialouri, E. (2009). Human factors and qualitative pedagogical evaluation of a mobile augmented reality system for science education used by learners with physical disabilities. Personal and ubiquitous computing, 13(3), 243-250. https:/ / doi.org/10.1007/s00779-007-0187-7

Augmented reality. (2019, September 29). In Wikipedia, the free encyclopedia. Retrieved on September 30, 2019 from https:/ / en.wikipedia.org/wiki/Augmented_reality

Augmented Reality: Mobile Architectural Applications of the Future. (2015, September 11). In Archspeech, the free electronic magazine. Retrieved on September 30, 2019 from https://archspeech.com/article/ dopolnennaya-real-nost-mobil-nye-arhitekturnye-prilozheniya-budushhego

Azuma, R. (1997). A Survey of Augmented Reality. Teleoperators and Virtual Environments, 6(4), 355-385. https:/ / doi.org/10.1162/ pres.1997.6.4.355

Azuma, R., Baillot, Y., Behringer, R., Feiner, S., Julier, S., \& MacIntyre, B. (2001). Recent advances in augmented reality. Computer Graphics and Applications IEEE, 21(6), 34-47. https:/ / doi.org/10.1109/38.963459

Bacca, J., Baldiris, S., Fabregat, R., \& Graf, S. (2014). Augmented reality trends in education: A systematic review of research and applications. Journal of Educational Technology \& Society, 17(4), 133-149.

Billinghurst, M., \& Duenser, A. (2012). Augmented reality in the classroom. Computer, 45(7), 56 -63. https://doi.org/10.1109/MC.2012.111

Blum, T., Kleeberger, V., Bichlmeier, C., \& Navab, N. (2012). Mirracle: an augmented reality magic mirror system for anatomy education. Virtual Reality Short Papers and Posters (VRW), 2012 IEEE, 115-116. https://doi.org/10.1109/VR.2012.6180909 
Bressler, D., \& Bodzin, A. (2013). A mixed methods assessment of students' flow experiences during a mobile augmented reality science game. Journal of Computer Assisted Learning, 29(6), 505-517. https:// doi.org/10.1111/jcal.12008

Bronack, S. C. (2011). The role of immersive media in online education. The Journal of Continuing Higher Education, 59(2), 113-117. https:// doi.org/10.1080/07377363.2011.583186

Burton, E. P., Frazier, W., Annetta, L., Lamb, R., Cheng, R., \& Chmiel, M. (2011). Modeling Augmented Reality Games with Preservice. Journal of Technology and Teacher Education, 19(3), 303-329.

Cai, S., Chiang, F. K., \& Wang, X. (2013). Using the augmented reality 3D technique for a convex imaging experiment in a physics course. International Journal of Engineering Education, 29(4), 856-865.

Cai, S., Wang, X., \& Chiang, F.K. (2014). A case study of augmented reality simulation system application in a chemistry course. Computers in Human Behavior, 37, 31-40. https:/ / doi.org/10.1016/j.chb.2014.04.018

Cascales-Martínez, A., Martínez-Segura, M.J., Pérez-López, D., \& Contero, M. (2017). Using an augmented reality enhanced tabletop system to promote learning of mathematics: A case study with students with special educational needs. Eurasia Journal of Mathematics Science and Technology Education, 13(2), 355-380. https:/ / doi.org/10.12973/eurasia.2017.00621a

Caudell, T. P., \& Mizell, D. W. (1992). Augmented reality: An application of heads-up display technology to manual manufacturing processes. Proceedings of the twenty-fifth Hawaii international conference on system sciences. https://doi.org/10.1109/HICSS.1992.183317

Chang, G., Morreale, P. A., \& Medicherla, P. S. (2010). Applications of augmented reality systems in education. Society for Information Technology \& Teacher Education International Conference, 2010, 1380-1385.

Chang, K.-E., Chang, C.-T., Hou, H.-T., Sung, Y.-T., Chao, H.-L., \& Lee, C.-M. (2014). Development and behavioral pattern analysis of a mobile guide system with augmented reality for painting appreciation instruction in an art museum. Computers E Education, 71, 185-197. https:/ / doi.org/10.1016/j.compedu.2013.09.022

Chang, W., Tan, Q., \& Tao, F.W. (2010). Multi-object oriented augmented reality for location-based adaptive mobile learning. Advanced Learning Technologies (ICALT), IEEE 10th International Conference, 450-451. https://doi.org/10.1109/ICALT.2010.130

Chang, Y.-J., Chen, C.-H., Huang, W.-T., \& Huang, W. (2011). Investigating students' perceived satisfaction, behavioral intention, and effectiveness of english learning using augmented reality. Multimedia and Expo (ICME), IEEE International Conference, 1-6.

Chang, Y.-L., Hou, H.-T., Pan, C.-Y., Sung, Y.-T., \& Chang, K.-E. (2015). Apply an augmented reality in a mobile guidance to increase sense of place for heritage places. Journal of Educational Technology E Society, 18(2), 166178.

Chen, C.-M., \& Tsai, Y.-N. (2012). Interactive augmented reality system for enhancing library instruction in elementary schools. Computers E Education, 59(2), 638-652. https:/ / doi.org/10.1016/j.compedu.2012.03.001

Chen, H., Feng, K., Mo, C., Cheng, S., Guo, Z., \& Huang, Y. (2011). Application of Augmented Reality in Engineering Graphics Education. International Symposium on IT in Medicine and Education (ITME 2011), Vol. 2, Guangzhou, China, December 9-11, 362-365. https:/ / doi.org/10.1109/ITiME.2011.6132125

Chen, Y.-C. (2006). A study of comparing the use of augmented reality and physical models in chemistry education. Proceedings of the 2006 ACM international conference on Virtual reality continuum and its applications, VRCIA, 369-372. https:/ / doi.org/10.1145/1128923.1128990

Cheng, K.-H., \& Tsai, C.-C. (2013). Affordances of augmented reality in science learning: Suggestions for future research. Journal of Science Education and Technology, 22(4), 449-462. https://doi.org/10.1007/s10956-0129405-9

Cheng, K.-H., \& Tsai, C.-C. (2016). The interaction of child-parent shared reading with an augmented reality (AR) picture book and parents' conceptions of AR learning. British Journal of Educational Technology, 47(1), 203222. https:/ / doi.org/10.1111/bjet.12228

Chiang, T. H. C., Yang, S. J. H., \& Hwang, G. (2014b). Students' online interactive patterns in augmented realitybased inquiry activities. Computers $\mathcal{E}$ Education, 78, 97-108. https:/ / doi.org/10.1016/j.compedu.2014.05.006

Chiang, T. H. C., Yang, S. J. H., \& Hwang, G. (2014a). An Augmented Reality-based Mobile Learning System to Improve Students' Learning Achievements and Motivations in Natural Science Inquiry Activities. Educational Technology \& Society, 17(4), 352-365.

Coffin, C., Bostandjiev, S., Ford, J., \& Hollerer, T. H. (2008). Enhancing Classroom and Distance Learning Through Augmented Reality. EdMedia: World Conference on Educational Media and Technology, 1140-1147. 
Corrêa, A. G. D., Ficheman, I. K., Nascimento, M., \& Lopes, R. (2009). Computer Assisted Music Therapy: A Case Study of an Augmented Reality Musical System for Children with Cerebral Palsy Rehabilitation. Proceedings - 9th IEEE International Conference on Advanced Learning Technologies, ICALT, 218-220. https://doi.org/10.1109/ICALT.2009.111

Dalim, C. S. C., Kolivand, H., Kadhim, H., Sunar, M. S., \& Billinghurst, M. (2017). Factors Influencing the Acceptance of Augmented Reality in Education: A Review of the Literature. Journal of Computer Science, 13(11), 581-589. https:/ / doi.org/10.3844/jcssp.2017.581.589

Davidsson, M., Johansson, D., \&. Lindwall, K. (2012). Exploring the use of augmented reality to support science education in secondary schools. Wireless, Mobile and Ubiquitous Technology in Education (WMUTE), IEEE Seventh International Conference, 218-220. https:/ / doi.org/10.1109/WMUTE.2012.52

Davies, R. S., Howell, S. L., \& Petrie, J. A. (2010). A review of trends in distance education scholarship at research universities in North America, 1998-2007. International Review of Research in Open and Distance Learning, 11(3), 42-56. https:/ / doi.org/10.19173/irrodl.v11i3.876

Dede, C. J. (2009). Immersive interfaces for engagement and learning. Science, 323(5910), 66-69. https://doi.org/10.1126/science.1167311

Delello, J. A., McWhorter, R. R., \& Camp, K. M. (2015). Integrating Augmented Reality in Higher Education: A Multidisciplinary Study of Student Perceptions. Journal of Educational Multimedia and Hypermedia, 24(3), 209233.

Di Serio, A., Ibanez, M. B., \& Kloos, C. D. (2013). Impact of an augmented reality system on students' motivation for a visual art course. Computers $\mathcal{E}$ Education, 68, 586-596. https:/ / doi.org/10.1016/j.compedu.2012.03.002

Dunleavy, M., Dede, C., \& Mitchell, R. (2009). Affordances and limitations of immersive participatory augmented reality simulations for teaching and learning. Journal of Science Education and Technology, 18(1), 7-22. https:/ / doi.org/10.1007/s10956-008-9119-1

El Sayed, N. A. M., Zayed, H. H., \& Sharawy, M. I. (2011). ARSC: Augmented reality student card. Computers $\mathcal{E}$ Education, 56(4), 1045-1061. https:/ / doi.org/10.1016/j.compedu.2010.10.019

Ferrer-Torregrosa, J., Torralba, J., Jimenez, M.A., García, S. \& Barcia, J.M. (2015). ARBOOK: Development and assessment of a tool based on augmented reality for Anatomy. Journal of Science Education and Technology, 24(1), 119-124. https:/ / doi.org/10.1007/s10956-014-9526-4

Garzón, J. \& Pavón, J. \& Baldiris, S. (2019). Systematic review and meta-analysis of augmented reality in educational settings. Virtual Reality. https:/ / doi.org/10.1007/s10055-019-00379-9

Gavish, N., Gutierrez, T., Webel, S., Rodríguez, J., Peveri, M., Bockholt, U. \& Tecchia, F. (2015). Evaluating virtual reality and augmented reality training for industrial maintenance and assembly tasks. Interactive Learning Environments, 23(6), 778-798. https:/ / doi.org/10.1080/10494820.2013.815221

Gu, J., Li, N., \& Duh, H. B.-L. (2011). A remote mobile collaborative AR system for learning in physics. In Virtual Reality Conference (VR), IEEE, 257-258. https:/ / doi.org/10.1109/VR.2011.5759496

Gün, E. T., \& Atasoy, B. (2017). The effects of augmented reality on elementary school students' spatial ability and academic achievement. Egitim ve Bilim, 42(191), 86-93.

Gutiérrez de Ravé, E., Jiménez-Hornero, F., Ariza Villaverde, A., \& Taguas-Ruiz, J. (2016). Mobile augmented reality system apply to Descriptive Geometry learning, 4741-4751. https:/ / doi.org/10.21125/edulearn.2016.2139

Han, J., Jo, M., Hyun, E., \& So, H.-J. (2015). Examining young children's perception toward augmented realityinfused dramatic play. Educational Technology Research and Development, 63(3), 455-474. https:/ / doi.org/10.1007/s11423-015-9374-9

Hsiao, K.-F. (2012). Using augmented reality for students healthcase of combining educational learning with standard fitness. Multimedia Tools and Applications, 1, 1-15.

Hsiao, K.-F., Chen, N.-S. \& Huang, S.-Y. (2012). Learning while exercising for science education in augmented reality among adolescents. Interactive Learning Environments, 20(4), 331-349. https:/ / doi.org/10.1080/10494820.2010.486682

Hsu, T. C. (2017). Learning English with augmented reality: Do learning styles matter? Computers $\mathcal{E}$ Education, 106, 137-149. https:// doi.org/10.1016/j.compedu.2016.12.007

Huang, Y., Li, H., \& Fong, R. (2016). Using augmented reality in early art education: A case study in Hong Kong kindergarten. Early Child Development and Care, 186(6), 879-894. https:// doi.org/10.1080/03004430.2015.1067888 
Hung, Y. H., Chen, C. H., \& Huang, S. W. (2017). Applying augmented reality to enhance learning: A study of different teaching materials. Journal of Computer Assisted Learning, 33(3), 252-266. https:/ / doi.org/10.1111/jcal.12173

Hwang, G.-J., \& Tsai, C.-C. (2011). Research trends in mobile and ubiquitous learning: A review of publications in selected journals from 2001 to 2010. British Journal of Educational Technology, 42(4), 65-70. https:// doi.org/10.1111/j.1467-8535.2011.01183.x

Hwang, G.-J., Tsai, C.-C., Chu, H.-C., Kinshuk, K., \& Chen, C.-Y. (2012). A context-aware ubiquitous learning approach to conducting scientific inquiry activities in a science park. Australasian Journal of Educational Technology, 28(5), 931-947. https:/ / doi.org/10.14742/ajet.825

Ibáñez, M. B., Di Serio, A., Villarán, D., \& Kloos, C.D. (2014). Experimenting with electromagnetism using augmented reality: Impact on flow student experience and educational effectiveness. Computers $\mathcal{E}$ Education, 71,1-13. https://doi.org/10.1016/j.compedu.2013.09.004

Joo-Nagata, J., Abad, F. M., Giner, J. G. B., \& García-Peñalvo, F. J. (2017). Augmented reality and pedestrian navigation through its implementation in m-learning and e-learning: Evaluation of an educational program in Chile. Computers \& Education, 111, 1-17. https:/ / doi.org/10.1016/j.compedu.2017.04.003

Juan, M. (2016). A mobile augmented reality system for the learning of dental morphology. Digital Education Review, 30, 234-247.

Kamarainen, A. M., Metcalf, S., Grotzer, T., Browne, A., Mazzuca, D., Tutwiler M. S., et al. (2013). EcoMOBILE: Integrating augmented reality and probeware with environmental education field trips. Computers $\mathcal{E}$ Education, 68, 545-556. https:/ / doi.org/10.1016/j.compedu.2013.02.018

Kaufmann, H. (2006). The potential of augmented reality indynamic geometry education. 12th International conference on geometry and graphics (ISGG6-10), Salvador, Brazil.

Kaufmann, H., \& Schmalstieg, D. (2003). Mathematics and geometry education with collaborative augmented reality. Computers \& Graphics, 27(3), 339-345. https:/ / doi.org/10.1016/S0097-8493(03)00028-1

Kaufmann, H., Steinbügl, K., Dünser, A., \& Glück, J. (2005). General Training of Spatial Abilities by Geometry Education in Augmented Reality. Annual Review of CyberTherapy and Telemedicine. A Decade of VR, 3, 6576.

Kerawalla, L., Luckin, R., Seljeflot, S., \& Woolard, A. (2006). «Making it real»: Exploring the potential of augmented reality for teaching primary school science. Virtual Reality, 10(3-4), 163-174. https:/ / doi.org/10.1007/s10055006-0036-4

Kirner, T. G., Reis, F. M. V., \& Kirner, C. (2012). Development of an interactive book with Augmented Reality for teaching and learning geometric shapes. Iberian Conference on Information Systems and Technologies, CISTI, 1, $1-6$.

Kiryakidi, S. (2014). Augmented reality and the prospects for its use in the construction industry. Retrieved on September 30, 2019 from http:/ / isicad.ru/ru/articles.php?article_num=16724

Li, J., Spek, E., Feijs, L., Wang, F., \& Hu, J. (2017). Augmented Reality Games for Learning: A Literature Review. Distributed, Ambient and Pervasive Interactions, 1, 612-626. https://doi.org/10.1007/978-3-319-58697-7_46

Lin, C. Y., \& Chang, Y. M. (2015). Interactive augmented reality using Scratch 2.0 to improve physical activities for children with developmental disabilities. Research in developmental disabilities, 37, 1-8. https:/ / doi.org/10.1016/j.ridd.2014.10.016

Lin, H.-C. K., Chen, M.-C., \& Chang, C.-K. (2015). Assessing the effectiveness of learning solid geometry by using an augmented reality-assisted learning system. Interactive Learning Environments, 23(6), 799-810. https:// doi.org/10.1080/10494820.2013.817435

Lin, H.-C. K., Hsieh, M.-C., Wang, C.-H., Sie, Z.-Y. \& Chang, S.-H. (2011). Establishment and usability evaluation of an interactive AR learning system on conservation of fish. The Turkish Online Journal of Educational Technology, 10(4), 181-187.

Lindgren, R., \& Johnson-Glenberg, M. C. (2013). Emboldened by embodiment six precepts for research on embodied learning and mixed reality. Educational researcher, 42(8), 445-452. https://doi.org/10.3102/0013189X13511661

Liu, P. H. E., \& Tsai, M. K. (2013). Using augmented-reality-based mobile learning material in EFL English composition: An exploratory case study. British Journal of Educational Technology, 44(1), 1-4. https:/ / doi.org/10.1111/j.1467-8535.2012.01302.x

Lu, S.-J. \& Liu, Y.-C. (2015). Integrating augmented reality technology to enhance children's learning in marine education. Environmental Education Research, 21(4), 525-541. https:/ / doi.org/10.1080/13504622.2014.911247 
Martin-Gutiérrez, J. M., \& Fernandez, M. D. M. (2014). Applying augmented reality in engineering education to improve academic performance \& student motivation. International journal of engineering education, 30(3), 625635.

Martin-Gutiérrez, J. M., García-Domínguez, M., Roca-González, C., Sanjuán-Hernan Pérez, A., \& MatoCarrodeguas, C. (2013). Comparative Analysis Between Training Tools in Spatial Skills for Engineering Graphics Students Based in Virtual Reality, Augmented Reality and PDF3D Technologies, Procedia Computer Science, 25, 360-363. https://doi.org/10.1016/j.procs.2013.11.043

Martín-Gutiérrez, J., Saorín, J. L., Contero, M., Alcañiz, M., Pérez-López, D. C., \& Ortega, M. (2010). Design and validation of an augmented book for spatial abilities development in engineering students. Computers $\mathcal{E}$ Graphics, 34(1), 77-91. https:/ / doi.org/10.1016/j.cag.2009.11.003

Matsutomo, S., Miyauchi, T., Noguchi, S., \& Yamashita, H. (2009). Real-Time Visualization System of Magnetic Field Utilizing Augmented Reality Technology for Education. IEEE Transactions on Magnetics - IEEE TRANS MAGN, 48, 531-534. https:/ / doi.org/10.1109/TMAG.2011.2174208

McMahon, D. D., Cihak, D. F., Wright, R. E., \& Bell, S. M. (2016). Augmented reality for teaching science vocabulary to postsecondary education students with intellectual disabilities and autism. Journal of Research on Technology in Education, 48(1), 38-56. https:/ / doi.org/10.1080/15391523.2015.1103149

Medina, E., Chen, Y.-C., \& Weghorst, S. J. (2008). Understanding Biochemistry with Augmented Reality. Proceedings of World Conference on Educational Multimedia, Hypermedia and Telecommunications 2007, 4235-4239.

Motokawa, Y., \& Saito, H. (2006). Support system for guitar playing using augmented reality display. Mixed and Augmented Reality, ISMAR. IEEE/ACM International Symposium, 1, $243 \quad-244$. https:/ / doi.org/10.1109/ISMAR.2006.297825

Munoz-Cristobal, J. A., Jorrin-Abellan, I. M., Asensio-Perez, J. I., Martinez-Mones, A., Prieto, L. P., \& Dimitriadis, Y. (2015). Supporting teacher orchestration in ubiquitous learning environments: A study in primary education. Learning Technologies. IEEE Transactions on Learning, 8(1), 83-97. https:/ / doi.org/10.1109/TLT.2014.2370634

Odeh, S., Shanab, S. A., Anabtawi, M., \& Hodrob, R. (2012). Remote augmented reality engineering labs. Global Engineering Education Conference (EDUCON), IEEE, 1, 1-6. https:/ / doi.org/10.1109/EDUCON.2012.6201162

Pellas, N., Fotaris, P., Kazanidis, I., \& Wells, D. (2018). Augmenting the learning experience in primary and secondary school education: a systematic review of recent trends in augmented reality game-based learning. VR in Education, 1-18. https: / doi.org/10.1007/s10055-018-0347-2

Pérez-López, D., Contero, M., \& Alcãiz, M. (2010). Collaborative development of an augmented reality application for digestive and circulatory systems teaching. In Advanced Learning Technologies (ICALT), IEEE 10th International Conference, 173-175. https:/ / doi.org/10.1109/ICALT.2010.54

Pires, J. F., Vecchia, L. D., \& Borda, A. A. Das. (2016). Transiting between Representation Technologies and Teaching/Learning Descriptive Geometry: Reflections in an Architectural Context. https:/ / doi.org/10.4018/978-1-5225-0029-2.ch011

Radu, I. (2012). Why should my students use AR? A comparative review of the educational impacts of AugmentedReality. ISMAR 2012 - 11th IEEE International Symposium on Mixed and Augmented Reality 2012, Science and Technology Papers, 1, 313-314. https:/ / doi.org/10.1109/ISMAR.2012.6402590

Radu, I. (2014). Augmented reality in education: A meta-review and cross-media analysis. Personal and Ubiquitous Computing, 18, 1533-1543. https://doi.org/10.1007/s00779-013-0747-y

Safar, A. H., Al-Jafar, A. A., \& Al-Yousefi, Z. H. (2017). The effectiveness of using augmented reality apps in teaching the English alphabet to kindergarten children: A case study in the State of Kuwait. Eurasia Journal of Mathematics, Science E Technology Education, 13(2), 417-440. https:/ / doi.org/10.12973/ eurasia.2017.00624a

Saidin, N. F., Abd Halim, N. D., \& Yahaya, N. (2015). A Review of Research on Augmented Reality in Education. Advantages and Applications. International Education Studies, 8(13), 1-9. https://doi.org/10.5539/ies.v8n13p1

Salinas, P., \& Pulido, R. (2017). Understanding the conics through augmented reality. Eurasia Journal of Mathematics, Science \& Technology Education, 13(2), 341-354. https:/ / doi.org/10.12973/ eurasia.2017.00620a

Santos, M. E. C., Chen, A., Taketomi, T., Yamamoto, G., Miyazaki, J., \& Kato, H. (2014). Augmented reality learning experiences: Survey of prototype design and evaluation. IEEE Transactions on Learning, 7(1), 38-56. https:/ / doi.org/10.1109/TLT.2013.37

Saracchini, R., Catalina, C., \& Bordoni, L. (2015). A Mobile Augmented Reality Assistive Technology for the Elderly. Comunicar, 23(45), 65-73. https:/ / doi.org/10.3916/C45-2015-07 
Shelton, B. E., \& Hedley, N. R. (2002). Using augmented reality for teaching earth-sun relationship to undergraduate geography students. The First IEEE International Augmented Reality Toolkit Workshop, 1, 1-8. https:// doi.org/10.1109/ART.2002.1106948

Shelton, B. E., \& Hedley, N. R. (2003). Exploring a Cognitive Basis for Learning Spatial Relationships with Augmented Reality. ITLS Faculty Publications, 1, 24-35.

Simeone, L., \& Iaconesi, S. (2010). Toys++ ar embodied agents as tools to learn by building. In Advanced Learning Technologies (ICALT), IEEE 10th International Conference, 649-650. https:/ / doi.org/10.1109/ICALT.2010.184

Simeone, L., \& Iaconesi, S. (2011). Anthropological conversations: Augmented reality enhanced artifacts to foster education in cultural anthropology. In Advanced Learning Technologies (ICALT), 2011 11th IEEE International Conference, 126-128. https:/ / doi.org/10.1109/ICALT.2011.43

Sin, A. K., \& Halimah, B. Z. (2010). Live Solar System (LSS): Evaluation of an Augmented Reality book-based educational tool, 1, 1-6. https:/ / doi.org/10.1109/ITSIM.2010.5561320

Singhal, S., Bagga, S., Goyal, P., \& Saxena, V. (2012). Augmented Chemistry: Interactive Education System. International Journal of Computer Applications, 49(15), 1-5. https:/ / doi.org/10.5120/7700-1041

Sirakaya, M., \& Alsancak Sirakaya, D. (2018). Trends in Educational Augmented Reality Studies: A Systematic Review. Malaysian Online Journal of Educational Technology, 6, 2-17. https:/ / doi.org/10.17220/mojet.2018.02.005

Sommerauer, P., \& Müller, O. (2014). Augmented reality in informal learning environments: A field experiment in a mathematics exhibition. Computers E Education, 79, 59-68. https:/ / doi.org/10.1016/j.compedu.2014.07.013

Sotiriou, S. A., \& Bogner, F. X. (2008). Visualizing the invisible: Augmented reality as an innovative science education scheme. Advanced Science Letters, 1(1), 114-122. https:/ / doi.org/10.1166/asl.2008.012

Squire, K. D., \& Jan, M. (2007). Mad City Mystery: Developing scientific argumentation skills with a place-based augmented reality game on handheld computers. Journal of Science Education and Technology, 16(1), 5-29. https:/ / doi.org/10.1007/s10956-006-9037-z

Squire, K. D., \& Klopfer, E. (2007). Augmented reality simulations on handheld computers. The Journal of the Learning Sciences, 16(3), 371-413. https:/ / doi.org/10.1080/10508400701413435

Sumadio, D. D., \& Rambli, D. R. A. (2010). Preliminary evaluation on user acceptance of the augmented reality use for education. Computer Engineering and Applications (ICCEA), Second International Conference, 2, 461-465. https://doi.org/10.1109/ICCEA.2010.239

Tarng, W., \& Ou, K.-L. (2012). A study of campus butterfly ecology learning system based on augmented reality and mobile learning. Wireless, Mobile and Ubiquitous Technology in Education (WMUTE), IEEE Seventh International Conference, 1, 62-66. https:/ / doi.org/10.1109/WMUTE.2012.17

Tekederea, H., \& Göke, H. (2016). Examining the Effectiveness of Augmented Reality Applications in Education: A Meta-Analysis. International journal of environmental $\&$ science education, 11(16), 9469-9481.

Tretyakova, Z. O., \& Merkulova, V. A. (2017). Augmented reality is a new step in the study of descriptive geometry. Proceedings of the XI St. Petersburg Congress «Professional Education, Science and Innovation in the XXI Century», St. Petersburg, 268-269.

Tretyakova, Z. O., Belov, N. V., Dementyeva, A. V., Otkupshikova, I. A., \& Reskov, K. N. (2018). Augmented reality in the learning process. Proceedings of the XLII student international scientific-practical conference «Scientific community of students: interdisciplinary research», Novosibirsk: Publishing House "SibAK", 7(42), 112-118.

Tretyakova, Z. O., Merkulova, V. A., \& Voronina, M. V. (2018). AR-technologies in the study of engineering graphics. Proceedings of the XII St. Petersburg Congress «Professional Education, Science and Innovation in the XXI Century", St. Petersburg, 240-241.

Veide, Z., Stroževa, V., \& Dobelis, M. (2014). Application of Augmented Reality for Teaching Descriptive Geometry and Engineering Graphics Course to First-Year Students. ICIT, 1-7.

Wang, Y. H. (2017). Exploring the Effectiveness of Integrating Augmented Reality-Based Materials to Support Writing Activities. Computers \& Education, 113, 162-176. https:/ / doi.org/10.1016/j.compedu.2017.04.013

Wang, Y. H. (2017). Using augmented reality to support a software editing course for college students. Journal of Computer Assisted Learning, 33(5), 532-546. https:/ / doi.org/10.1111/jcal.12199

Wei, X., Weng, D., Liu, Y., \& Wang, Y. (2015). Teaching based on augmented reality for a technical creative design course. Computers E Education, 81, 221-234. https:/ / doi.org/10.1016/j.compedu.2014.10.017

Wu, H.-K., Lee, S. W.-Y., Chang, H.-Y., \& Liang, J.-C. (2013). Current status, opportunities and challenges of augmented reality in education. Computers $\mathcal{E}$ Education, 62, 41-49. https:/ / doi.org/10.1016/j.compedu.2012.10.024 
Wu, W.-H., Wu, Y.-C.J., Chen, C.-Y., Kao, H.-Y., Lin, C.-H., \& Huang, S.-H. (2012). Review of trends from mobile learning studies: A meta-analysis. Computers $\mathcal{E}$ Education, 59(2), 817-827. https://doi.org/10.1016/j.compedu.2012.03.016

Yang, S., Mei, B., \& Yue, X. (2018). Mobile Augmented Reality Assisted Chemical Education: Insights from Elements 4D. Journal of Chemical Education, 95, 1060-1062. https://doi.org/10.1021/acs.jchemed.8b00017

Yilmaz, R. M. (2018). Augmented Reality Trends in Education between 2016 and 2017 Years, State of the Art Virtual Reality and Augmented Reality Knowhow, IntechOpen. https://doi.org/10.5772/intechopen.74943

Yilmaz, R. M., Kucuk, S., \& Goktas, Y. (2016). Are augmented reality picture books magic or real for preschool children aged five to six?: Augmented Reality Picture Books for Preschool Students. British Journal of Educational Technology, 48, 265-276. https://doi.org/10.1111/bjet.12452

Yoon, S. A., Elinich, K., Wang, J., Steinmeier, C., \& Tucker, S. (2012). Using augmented reality and knowledgebuilding scaffolds to improve learning in a science museum. International Journal of Computer-Supported Collaborative Learning, 7(4), 519-541. https:/ / doi.org/10.1007/s11412-012-9156-x

Yu, D., Jin, J. S., Luo, S., Lai, W., \& Huang, Q. (2009). A useful visualization technique: A literature review for augmented reality and its application, limitation \& future direction. Visual information communication, 1, 311337. https:/ / doi.org/10.1007/978-1-4419-0312-9_21

Zainuddin, N. M. M., Badioze Zaman, H. Z., \& Ahmad, A. (2010). A participatory design in developing prototype an Augmented Reality Book for deaf students. 2nd International Conference on Computer Research and Development, ICCRD 2010, 400-404. https:/ / doi.org/10.1109/ICCRD.2010.55

Zarraonandia, T., Aedo, I., Díaz, P. M., \& Montero, A. (2013). An augmented lecture feedback system to support learner and teacher communication. British Journal of Educational Technology, 44(4), 616-628. https:/ / doi.org/10.1111/bjet.12047

Zhang, J., Sung, Y.-T., Hou, H.-T., \& Chang, K.-E. (2014). The development and evaluation of an augmented realitybased armillary sphere for astronomical observation instruction. Computers $\mathcal{E}$ Education, 73, 178-188. https:/ / doi.org/10.1016/j.compedu.2014.01.003

\section{http://www.ejmste.com}

